\title{
STAVOVI VASPITAČA O ZNAČAJU KLJUČNIH OBRAZOVNIH KOMPETENCIJA ZA CELOŽIVOTNO UČENJE U RADU SA DECOM PREDŠKOLSKOG UZRASTA
}

\begin{abstract}
Rezime: $\mathrm{U}$ teorijskom delu rada biće reči o uticaju globalnih promena na shvatanje obrazovanja i ciljeve obrazovanja. Te promene dovode do implementacije novih koncepata u formalno obrazovanje, kao što su celoživotno učenje i ključne kompetencije za celoživotno učenje. Nove koncepcije neizostavni su deo svih nivoa obrazovanja, a u ovom radu akcenat će biti na predškolskom nivou. $U$ predškolskom uzrastu najveći uticaj na razvoj dece imaju roditelji, vaspitači i zajednica u kojoj dete živi. Cilj istraživanja bio je da se ispitaju stavovi vaspitača o značaju vaspitno-obrazovnog rada sa decom predškolskog uzrasta na razvoju pojedinačnih ključnih obrazovnih kompetencija za celoživotno učenje, odnosno da se uvidi kojim kompetencijama vaspitači daju prednost u radu, a kojima ne pridaju poseban značaj. Korišćeni su rezultati istraživanja koje je sprovedeno u julu i avgustu 2019. godine, na uzorku od 149 vaspitača sa teritorije Beograda, Pančeva i Ivanjice. Korišćena je deskriptivna metoda. Tehnika koju smo koristili je anketiranje, a instrument anketni upitnik. Rezultati istraživanja ukazuju da vaspitači najveći značaj pridaju razvoju kompetencija pismenosti i matematičkim kompetencijama i da postoji razlika u pridavanju značaja određenim kompetencijama u radu sa decom predškolskog uzrasta, koje su uslovljene godinama radnog staža i mestom rada vaspitača. Izdojili bismo digitalne i jezičke kompetencije kao kompetencije kojima vaspitači pridaju najmanji značaj u radu sa decom predškolskog uzrasta, što se kosi sa trendovima u oblasti obrazovanja.
\end{abstract}

Ključne reči: ključne obrazovne kompetencije za celoživotno učenje, deca predškolskog uzrasta, vaspitač.

Uvod

Neminovno je da se svet veoma brzo menja. Naučna i tehnološka otkrića dešavaju svakodnevno i za sobom povlače promene na ekonomskom, političkom, socijalnomnivou kao i nove potrebe društva u celini. Ono što je pri ovim promenama neophodno jeste da čovek (društvo) ide u korak s njima. Ljudi u srednjem životnom dobu su formalno obrazovanje završili krajem prošlog veka, a nije neophodno naglasiti do kojih sve novih saznanja se došloi kako su ona uticala i danas utiču na funkcionisanje društva. Neka zanimanja za koje su se ljudi tada školovali sada ne postoje, ali je još veći broj novootvorenih radnih mesta o kojima nije ni bilo reči pre 20 godina što može predstavljati izazove za obrazovanje. A može se samo pretpostaviti koje su to delatnosti kojima će se nove generacije baviti u budućnosti. To bi u 
budućnosti moglo da izazove neophodna velika ulaganja u sticanje znanja,veština i navika i u opsežno promišljanje koncepta obrazovanja i celoživotnog učenja.

Nekadašnja parola radnika glasila je "posao za celi život", ali se ona usled ubrzanih promena u privredi i tehnologijama definitnivno promenila. Ono što je sada aktuelno jeste karijera na više radnih mesta sa neophodnim stalnim usavršavanjem i radom na sebi, tj. nasvojim znanjima, sposobnostima i veštinama (Vuorinen\&Vats, 2014). Ovo za sobom povlači neophodnost konstantnog učenja i usavršavanja sopstvenih veština i sposobnosti, tj. potrebu za celoživotnim učenjem, kao i brzu adaptaciju na nove uslove u kojima se pojedinac može naći.

Prema Maksimović (Maksimovic, 2012) današnji svet se nalazi u procesu tranzicije iz industrijske ere u informacionu i komunikacionu eru koja se često označava kao "društvo učenja" ili "učeno društvo". Takvo društvo zahteva različite vrste učenja koje vode ka stalnom i celoživotnom učenju, zapošljavanju i ličnom razvoju svakog pojedinca.

Možemo reći da je u toku ove digitalne ere i ekspanzije informacionih tehnologija svet mnogo napredovao. Međutim i pored svih tehnologija, mašina, kompjutera, robota i sl. za napredak, razvoj, uspešnost i dugovečnost nekog preduzeća ili organizacije nije toliko presudna tehnologija, logistika i slično koliko kvalitet ljudskih potencijala. To je razlog zbog koga se više pažnje posvećuje radu centara za ljudske potencijale da bi se pronašli novi načini kako na tržištu rada obezbediti adekvatne kadrove koji su sposobni da rastu i razvijaju se obogaćivanjem broja svojih kompetencija u skladu sa potrebama radnih organizacija u kojima se zapošljavaju (Prastalo, 2010).

Analize na tržištu rada, kako navodi Maksimović (Maksimovic, 2012) pokazuju da se od zaposlenih traži da se kontinuirano usavršavaju, da budu kreativni i inovativni u rešavanju problema i komuniciranju, da budu samostalni u radu, da poseduju širok opseg veština i sposobnosti, da imaju razvijeno kritičko mišljenje, da rade u timu i imaju veštine donošenja odluka ida se brzo adaptiraju na nove promene.

Usled ekonomskog i tehnološkog razvoja pojavljuje se niz različitih mera, incijativa i preporuka od strane različitih tela EU kako bi se se pružila podrška izazovima sa kojima se zemlje članice EU suočavaju, a one su veome često podjednako relevantne i za zemlje kandidate (Manic Radoicic i Durovic, 2018). Srbija je jedna od zemalja koja pokazuje zainteresovanost za ove inicijative i aktivno učestvuje u sprovođenju istih.

\section{Teorijski deo}

Prethodno navedene promene dovode i do promena u shvatanju obrazovanja i ciljeva obrazovanja. Jasno je da obrazovanje ne može, niti je njegova uloga da rešava pitanje nezaposlenosti, ali je neminovno da u velikoj meri utiče na procese zapošljavanja i samu politiku zaposlenosti. Od kavilteta obrazovanja zavisi koliko kompetentne ljude će poslati u svet rada, sa kakvim navikama, znanjima, sposobnostima i veštinama, kao i to hoće li oni biti zainteresovani za neformalno i informalno obrazovanja, a sve u cilju ličnog usavršavanja i napredovanja (Maksimovic, 2012). Odnosno možemo reći da globalne promene (in)direktno utiču na promene u shvatanju obrazovanja i ciljeva obrazovanja, kreiranje obrazovnih politika, osmišljavanje strategija, okvira itd. 
Na Lisabonskoj konferenciji Saveta Evrope (mart 2000) celoživotno učenje je dobilo još veći značaj, jer je zaključeno da je to glavni okvir i princip daljeg razvoja, ne samo evropskog obrazovanja, već i čitavog evropskog društva. Stvaranje „učene Evrope“ jedan je od osnovnih ciljeva koji je definisala Lisabonska deklaracija (Maksimovic, 2012).

Mnogi faktori koji deluju u nacionalnom i međunarodnom obrazovnom i javnom prostoru definišu potrebu da se obrazovni sistem restrukturira menjanjem sadržaja, oblasti primene znanja i pristupa nastavi i učenju. Neki od najvažnijih faktora su: globalna orijentacija ka kompetencijama; uticaj novih tehnologija, interneta i medija na učenje, prirodu poslova i privatni život pojedinca; rastuća socijalna mobilnost i rastuća konkurentnost na tržištu rada (Standardi opstih međupredmetnih kompetencija za kraj srednjeg obrazovanja, 2013).

U odnosu na već gore pomenuto, cilj obrazovanja ne treba da se ogleda u količini usvojenog i tačno (sadržajno) određenog znanja (što prepoznajemo u praksi), već u kvalitetu tog znanja i načinima na koje smo do tih znanja došli, kao i u spremnosti da to znanje nadograđujemo i koristimo u različitim situacijama i okolnostima. Zbog brzine promena i enormnog rasta korpusa znanja u svim oblastima ne možemo se oslanjati na znanja koja smo dobili putem formalnog obrazovanja (Nacionalni prosvetni savet, 2011). Ono što svakako objašnjava i olakšava ovu promenu je činjenica da su nam skoro sve neophodne informacije iz najrazličitijih oblasti široko dostupne na samo "klik" od nas.

Globalizacija utiče, kao što je već rečeno, na promene u obrazovanju koje se ogledaju u načinu sticanja znanja, posebno: da znanje bude praktično i primenljivo i da odgovara potrebama tržišta, da je znanje put ka ličnom uspehu i ličnoj promociji, te znanje koje doprinosi konkurentnosti u daljem razvoju proizvodnje i sticanje većeg profita. Naglasak je na razvijanju spretnosti, veština i različitih načina komunikacije. Sve te promene idu u pravcu smanjivanja opšteg humanističkog obrazovanja i odgovarajućih humanističkih predmeta i njihovih sadržaja, što je nametnulo pitanje odnosa globalnih i nacionalnih ciljeva i vrednosti.

Kako ove promene zahtevaju sistemske reforme, odnosno promenu formalnog obrazovanja, za šta je neophodno dosta vremena, dolazi do toga da se ljudi, uporedo ili nakon formlanog obrazovanja,opredeljuju za različite načine razvijanja sopstvenih potencijala, pohađaju različite kurseve i obuke, stiču priznate sertifikate i diplome, ne bi li zadovoljili potrebu za sticanjem novih veština, znanja i sposobnosti koje bi im omogućile lakše zaposlenje ili kako bi prosto otvorili sebi širu lepezu mogućnosti za zaposlenjem ili samoaktualizacijom.

Rezolucija Saveta o novim veštinama za nove poslove² (2007) (eng. The Council Resolutionon new skills for new jobs) poziva države članice da podignu nivo razvijenosti veština i da pruže obrazovanje i obuke za sticanje veština, da realizuju mere za smanjivanje neusklađenosti postojećih i traženih veština i da pružaju usluge karijernog vođenja i davanja informacija o veštinama za nove poslove. Rezolucija takođe naglašava važnost kontinuiranog rada na validaciji stečenog znanja kroz formalno, neformalno i informalno obrazovanje (Manic Radoicic i Durovic 2018).

${ }^{2} U$ ovom dokumentu možete videti kratak pregled predloženih mera za harmonizaciju sistema obrazovanja i obuka za sticanje neophodnih veština u dokumentima EU. 
O znanjima i veštinama koji su trenutno neophodni i popularni se malo govori u redovnom školovanju, tj. tokom formalnog obrazovanja. To je dovelo, kao što je već pomenuto, do ekspanzije neformalnog obrazovanja. Pod neformalnim obrazovanjem podrazumevamo organizovano učenje koje se sprovodi van redovnog školskog obrazovanja,a koji podrazumeva aktivnosti poput seminara, predavanja, konferencija, radionica itd.. Ovde je zgodno pomenuti i informalni vid obrazovanja koji se zasniva na ličnom iskustvu, usvojenim društvenim vrednostima i samoinicijativnom učenju (Prastalo, 2010, Pavicevic, Petrovic, 2015). Ova tri oblika obrazovanja čine jednu celinu, čine osnovu celoživotnog ućenja, ali bi se kao problem ovde moglo izdvojiti koje vrste znanja i sadržaji bi se sticali i usvajali putem formalnog obrazovanja, a koje putem neformlanog i informalnog obrazovanja. Neformalno obrazovanje je dopuna formalnom, fleksibijlnije je, pa se zato brže prilagođava društvenim potrebama, a tu pre svega mislimo na potrebe privrede i zapošljavanja i brže dovodi do formiranja neophodnih kompetencija (Nacionalni prosvetni savet, 2011). Međutim, cilj je da do kraja formlanog obrazovanja mladi ljudi razviju ključne kompetencije i na taj način se pripreme za život odrasle i zrele osobe koja će biti sposobna da se dalje razvija i proširuje listu svojih kompetencija kroz čitav život (Vukovic, 2015). Sa ovim se slaže i Dmitrović (Dmitrovic 2011) ističući da nove zahteve društva nije moguće ostvariti kroz tradicionalnu nastavu, koja je orjentisana na prenošenje činjenica i informacija, već kroz otvoren i fleksibilan sistem koji se prilagođava potrebama društva znanja. Sve to ne može postići sam rukovodilac vaspitno-obrazovne ustanove i zato je neophodno formirati menadžment timove za planiranje i implementaciju postavljenih ciljeva i zadataka svake vaspitno-obrazovne institucije.

Već je Lisabonskom strategijom 2000. godine uočen izazov prilagođavanja sistema obrazovanja i obuka u Evropi zahtevima društva znanja i potrebi za povećanjem stope i kvaliteta zapošljavanja. Prepoznaje se potreba za razvojem bazičnih veština, naročito onih koje su u vezi sa informacionim tehnologijama, važnost razvoja veština kroz celoživotno učenje i povećane transparentnosti kvalifikacija i mobilnosti. U skladu sa strategijom Konkretni budući ciljevi sistema obrazovanja usvojenog 2001. godine (eng. The Concrete Future Objectives of Education Systems) ključan pravac za razvoj veština u budućnosti jeste identifikovanje bazičnih veština potrebnih za društvo znanja (Manic Radoicić, Durovic, 2018).

Zbog toga se danas govori o kompetencijama kao mehanizmu ili načinu da se pojedinac dobro opremi za današnji, a posebno sutrašnji svet. Definisanje takvih kompetencija koje mogu da pomognu i obezbede ocenu kako su mladi ljudi i odrasli spremni za životne izazove, određuje i utiče na ciljeve obrazovanja i celoživotnog učenja (Maksimovic, 2012)3.

Evropski parlament i Veće (European Parliament and the Council, 2006) doneli su 2006. godine Preporuku o ključnim kompetencijama za celoživotno učenje. Ovime se državama članicama preporučuje da omoguće i razvoj ključnih kompetencija za sve u sklopu strategija celoživotnog učenja. U priloženom dokumentu „Evropski referentni okvir ključnih kompetencija“ definisano je osam ključnih kompetencija za celoživotno učenje koje su neophodne svakom pojedincu za lično ispunjenje i razvoj, zapošljavanje socijalnu uključenost i aktivno građanstvo. Od država članica zatraženo je da se služe Referentnim okvirom kako bi osigurale da se inicijalnim obrazovanjem i osposobljavanjem svim mladim ljudima omogući razvoj ključnih kompetencija do nivoa koji ih osposobljava za život odraslih, i da odrasle osobe mogu dalje razvijati ključne kompetencije tokom celog života. Lista ključnih obrazovnih kompetencija

3 Za kratak pregled različitog definisanja pojma kompetencija videti Maksimović, 2012. 
navedena u ovom dokumentu je redefinisana u dokumentu iz 2018. godine (European Commission, 2018a).

U dokumentu Evropske komisije Preporuke veća o ključnim kompetencijama za celoživotno učenje (European Commission, 2018a) obrazlaže se potreba za definisanjem ključnih kompetencija za celoživotno učenje. U evropskim društvima i vlastima, dešavaju se brojne digitalne i tehnološke inovacije usled kojih nastaju promene na tržištu rada i demografske promene. Dolazi se do zaključka da više nije dovoljno deci preneti unapred određen skup znanja ili veština, već oni moraju da razviju otpornost, širok raspon kompetencija i sposobnost prilagođavanja promenama.

Glavni ciljevi Referentnog okvira (European Commission, 2018a) su prepoznavanje i definisanje ključnih kompetencija potrebnih za zaposlenje, lično ispunjenje, aktivno građanstvo i socijalnu uključenost; osigurati evropski referentni alat za ljude koji upravljaju obrazovnom politikom, prosvetne radnike, poslodavce $\mathrm{i}$ same učenike $\mathrm{i}$ podupirati napore na evropskom, nacionalnom, regionalnom i lokalnom nivou kako bi se podsticao razvoj kompetencija iz perspektive celoživotnog učenja. Pri tome u Referentnom okviru (European Commission, 2018a) pod kompetencijama podrazumevamo kombinaciju znanja, veština i stavova pri čemu: znanje se sastoji od već postojećih činjenica i podataka, koncepata, ideja i teorija koje podupiru razumevanje određenog područja ili teme; veštine se definišu kao sposobnost i mogućnost sprovođenja procesa i korišćenja postojećim znanjem za postizanje rezultata; stavovi opisuju spremnost na delovanje ili reagovanje na ideje, osobe ili situacije i povezani način razmišljanja. Ključne kompetencije su nešto što treba svim pojedincima za lično ispunjenje i razvoj, zaposlenje, socijalnu uključenost i aktivno građanstvo. Razvijaju se u okviru celoživotnog učenja, od ranog detinjstva do odraslog doba, kroz formalno, neformalno i informalno učenje.

Pitanje kako obrazovanje da pruži pojedincima ključne kompetencije i kako da ih pripremi za izmenjene uslove rada i života postaje jedno od strateških pitanja daljeg razvoja obrazovanja u Srbiji (Maksimovic, 2012).Ključne kompetencije čine suštinu društva zasnovanog na znanju i omogućavaju, čak garantuju veću fleksibilnost u kretanju kroz tržište rada, bržu adaptaciju na promene u svetu ekonomije i proizvodnje i omogućavaju mobilnost. $U$ isto vreme, ključne kompetencije treba da doprinesu inovativnosti, konkurentnosti i motivaciji i zadovoljstvu radnika.

U dokumentu Evropske komisije „Prilog prijedlogu preporuke Vjeća o ključnim kompetencijama za cjeloživotno učenje“ (European Commission,2018b) iz 2018. godine navode se sledeće kompetencije: Kompetencije pismenosti, jezičke kompetencije, matematičke kompetencije i kompetencije u prirodnim naukama, tehnologiji i inženjerstvu, digitalne kompetencije, lične i socijalne kompetencije i kompetencije učenja, građanske kompetencije, kompetencije preduzetništva i kompetencije kulturne svesti i izražavanja.

\section{Implemenacija ključnih kompetencija u predškolsko vaspitanje i obrazovanje}

Ključne kompetencije za celoživotno ugrađene su u ciljeve i standarde na svim nivoima obrazovanja kao nove oblasti, relevantne za kontinuirano sticanje kompetencija, vođenje privatnog i društvenog života, profesiju i snalaženje u realnim problemima i zahtevnim situacijama (Zakon o nacionalnom okviru kvalifikacija, 2020). 
Ključne obrazovne kompetencije za celoživotno učenje u predškolskom vaspitanju i obrazovanju u Srbiji, predstavljene su u Pravilniku o osnovama programa predškolskog vaspitanja i obrazovanja (2018). To su: komunikacija na maternjem jeziku, komunikacija na drugom jeziku, matematičke, naučne i tehnološke kompetencije, digitalna kompetencija, učenje učenja, društvene i građanske kompetencije, inicijativa i preduzetništvo i kao poslednja, kulturološka svest i izražavanje.U ovom dokumentu ključne obrazovne kompetencije su navedene prema dokumentu iz 2006. godine, a ne prema revidiranom dokumentu iz 2018. godine, što je sasvim razumljivo jer su oba dokumenta objavljena 2018. godine.

Brojne analize (UNESCO, UNICEF, Svetska banka, OEBS) ukazuju da investiranje u rano vaspitanje i obrazovanje obezbeđuje značajne ekonomske uštede u kasnijim obrazovnim cklusima, daju osnovu za celokupni razvoj osobe i daje značajne socijalne i ekonomske efekte (smanjuje se stopa odustajanja od daljeg školovanja, utiče se na smanjenje maloletne delinkvencije, snažna je mera protiv školskog neuspeha, siromaštva i socijalne isključenosti) (Woodhead, 2007, Strategija razvoja obrazovanja u Srbiji do 2020. Godine, 2012). Ovo se posebno odnosi na decu iz marginalizovanih grupa. Predškolsko vaspitanje se shvata kao prva faza u koncepciji celoživotnog obrazovanja.

Promene se primećuju i implementiraju u programima rada predškolskih ustanova. Tako je u Srbiji postojeće tematsko planiranje u kom je vaspitač imao dominantnu ulogu i bio odgovoran za usvajanje novih i proširivanje postojećih znanja, obogaćenaprojektnim planiranjem u kojem bi cilj učenja bio traženje odgovora na pitanja koja decu interesuju, koja su njima smislena (Budevac, Kovacevic, 2020). Akcenat nije na deklarativnim znanjima koja će deca akumulirati, kao što je pre u tekstu pomenuto, već na samom procesu dolaženja do odgovora na postavljena pitanja, gde mogu otići, ko ih može posetiti itd. Ono što se očekuje od predškolskog i osnovnoškolskog vaspitanja i obrazovanja dece u Srbiji, prema Kovačević (Kovacevic, 2017) je da podstiču samostalnost dece i razvijaju sposobnosti za samostalno učenje. Glavni cilj formalnog obrazovanja treba da bude opremanje dece/učenika intelektualnim alatima i njihovo osposobljavanje za samoregulisano učenje, jer upravo takvi lični resursi omogućavaju pojedincu doživotno učenje.

U novim Osnovama programa predškolskog vaspitanja i obrazovanja (Godine uzleta, 2018) nailazimo na koncept kompetencija za celoživotno učenje, što je očekivano jer se baš u najranijem uzrastu, tj. predškolskom dobu postavljaju temelji za razvoj kompetencija za celoživotno učenje. Rad na razvoju svake od pojedinačnih kompetencija usklađen je sa mogućnostima dece u ovom periodu.

Ono što možemo primetiti jeste da su neke od kompetencija zaista prepoznate kao neophodne, ključne obrazovne kompetencije, kao što su digitalne kompetencije ili komunikacija na drugom (stranom) jeziku. Značaj tih kompetencija je odavno prepoznat i preduzete su određene mere kako bi se doprinelo razvoju tih kompetencija. Pregledom različite literature uvideli smo da se prednost daje digitalnim i jezičkim kompetencijama, pre svega. Upravo to je bio razlog da sprovedemo ovo istraživanje.

Jednu od glavnih uloga u pružanju podrške razvoju ključnih kompetencija za celoživotno učenje kod dece predškolskog uzrasta ima vaspitač. Vaspitač je taj koji strukturira prostor i materijale, stvara okruženje pogodno za istraživanje i učenje, bira sadržaje i aktivnosti u skladu sa dečijim interesovanjima, u skladu sa svojom procenom načemu je neophodno raditi više ili manje. 


\section{Metodologija istraživanja}

Sprovedeno je veće empirijsko istraživanje koje je imalo za cilj ispitivanje odnosa vaspitača prema prirodnim naukama i njihovi stavovi o značaju razvoja naučnih kompetencija kod dece predškolskog uzrasta. Korišćena je deskriptivna metoda sa anketiranjem kao istraživačkom tehnikom. U okviru ovog rada biće prikazani rezultati koji se odnose na ispitivanje stavova vaspitača o značaju vaspitno-obrazovnog rada na razvoju ključnih obrazovnih kompetencija za celoživotno učenje sa decom predškolskog uzrasta.

Na vaspitače gledamo kao na osobe koje imaju značajan uticaj na razvoj ključnih kompetencija za celoživotno učenje, odnosno na osobe čija uverenja o važnosti razvoja ključnih obrazovnih kompetencija i od ličnih kompetencija (pedagoških kompetencija u užem i širem smislu)zavisi da li će se, na koji način i u kojoj meri pružati deci podršku u razvijanju ovih kompetencija. Korišćena je deskriptivna metoda. Tehnika je anketiranje, a instrument anketni upitnik. U istraživanju je učestvovalo 149 vaspitača sa teritorije Beograda, Pančeva i Ivanjice (Tabela 1). Podatke prikupljene istraživanjem interpretirali smo i analizirali prema dve nezavisne varijable: mesto rada vaspitača (u daljem tekstu mesto) i godine radnog staža (u daljem tekstu GRS). Koristili smo podatke istraživanja iz jula i avgusta 2019. godine.

Tabela 1: Struktura uzorka

\begin{tabular}{|c|c|c|c|c|c|c|c|c|}
\hline \multirow{2}{*}{ Mesto } & \multicolumn{6}{|c|}{ Godine radnog staža u tri grupe } & \multirow{2}{*}{\multicolumn{2}{|c|}{ Ukupno }} \\
\hline & & Do 10 GRS & & & & RS & & \\
\hline Beograd & 27 & $45,0 \%$ & 17 & $28,3 \%$ & 16 & $26,7 \%$ & 60 & $100,0 \%$ \\
\hline Manji grad & 14 & $23,3 \%$ & 30 & $50,0 \%$ & 16 & $26,7 \%$ & 60 & $100,0 \%$ \\
\hline Selo & 15 & $51,7 \%$ & 7 & $24,1 \%$ & 7 & $24,1 \%$ & 29 & $100,0 \%$ \\
\hline Ukupno & 56 & $37,6 \%$ & 54 & $36,2 \%$ & 39 & $26,2 \%$ & 149 & $100,0 \%$ \\
\hline
\end{tabular}

\section{Rezultati i diskusija}

Vaspitačima je data tabela u kojoj su sa jedne strane bile tvrdnje napisane tako da svaka tvrdnja odgovara opisu jedne ključne obrazovne kompetencije. Zbog kompleksnosti matematičkih, naučnih i tehnoloških kompetencije one su u dve tvrdnje tako da jedna tvrdnja odgovara matematičkim, a druga naučnim kompetencjama. Na spisak svih ovih kompetencija dodata je i tvrdnja koja se odnosi na lične kompetencije koje se nalaze u dokumentu iz 2018. godine (European Commission,2018b).U nastavku svake tvrdnje nalazili se se brojevi od 1 do 5 . Vaspitači su u odnosu na te tvrdnje zaokružili broj od 1 do 5 (1 - uopšte nije značajno, 2 - nije značajno, 3 - delimično je značajno, 4- značajno je, 5 - veoma je značajno) u odnosu na to koliki značaj pridaju svakoj od pojedinačnih kompetancija u radu sa decom predškolskog uzrasta.

Ne uzimajući u obzir varijable, a prema prosečnoj skalnoj vrednosti za svaku od ponuđenih kompetencija, u Tabeli 2 prikazane su ključne obrazovne kompetencije prema rangu za celokupan uzorak: 
Tabela 2. Srednja vrednost pojedinačnih kompetencija za celokupan uzorak

\begin{tabular}{|c|c|c|}
\hline Rang & Kompetencije: & $M$ \\
\hline 1. & $\begin{array}{l}\text { Bogaćenje rečnika i osposobljavanje za korišćenje različitih funkcija jezika (usmeno } \\
\text { izražavanje, jezičko stvaralaštvo, grafičko i simboličko predstavljanje...) - Kompetencije } \\
\text { pismenosti }\end{array}$ & 4,83 \\
\hline 2. & $\begin{array}{l}\text { Razvijanje i primena logičko-matematičkog mišljenja (sagledavanje i razumevanje } \\
\text { pojava i odnosa i rešavanje problema) - Matematičke kompetencije }\end{array}$ & 4,73 \\
\hline 3. & $\begin{array}{l}\text { Razvijanje sposobnosti promišljanja o sebi, svojoj fizičkoj i emocionalnoj dobrobiti i } \\
\text { prepoznavanja vlastitih mogućnosti i interesovanja - Lične kompetencije }\end{array}$ & 4,68 \\
\hline 4. & $\begin{array}{l}\text { Razvijanje svesti o sebi kao odgovornom članu različitih društvenih grupa i } \\
\text { osposobljavanje za aktivno učestvovanje u građanskom i društvenom životu - } \\
\text { Građanske kompetencije }\end{array}$ & 4,54 \\
\hline 5. & $\begin{array}{l}\text { Razvijanje sposobnosti upravljanja procesom vlastitog učenja (promišljanje, planiranje, } \\
\text { preispitivanje, pronalaženje izvora, upravljanje vremenom i resursima, odlučivanje...) - } \\
\text { Kompetencije učenja }\end{array}$ & 4,44 \\
\hline 6. & $\begin{array}{l}\text { Razvijanje sposobnosti promišljanja o sebi, svojoj fizičkoj i emocionalnoj dobrobiti i } \\
\text { prepoznavanja vlastitih mogućnosti i interesovanja - Kompetencije kulturne svesti i } \\
\text { izražavanja }\end{array}$ & 4,43 \\
\hline 7. & $\begin{array}{l}\text { Razvijanje preduzetničkih veština (strateško razmišljanje, rešavanje problema, } \\
\text { kreativni pristup procesima i inovacijama, vršenje izbora, preuzimanje inicijative, } \\
\text { prihvatanje odgovornosti ...) - Preduzetničke kompetencije }\end{array}$ & 4,34 \\
\hline 8. & $\begin{array}{l}\text { Proširivanje znanja o prirodnim i fizičkim pojavama, upoznavanje sa tehnikama } \\
\text { istraživanja u prirodnim naukama u njihovo ovladavanje na elementarom nivou - } \\
\text { Kompetencije u prirodnim naukama, tehnologiji i inženjerstvu }\end{array}$ & 4,33 \\
\hline 9. & $\begin{array}{l}\text { Razvijanje svesti i znanja o različitim kulturama i jezicima i situaciono usvajanje drugog } \\
\text { (stranog) jezika - Jezičke kompetencije }\end{array}$ & 3,87 \\
\hline 10. & $\begin{array}{l}\text { Razvijanje sposobnosti smislenog korišćenja digitalnih tehnologija na elementarnom } \\
\text { nivou (prikupljanje informacija, izražavanje i predstavljanje, dokumentovanje, } \\
\text { zauzimanje odgovornog i kritičkog odnosa prema upotrebi digitalnih tehnologija...) - } \\
\text { Digitalne kompetencije }\end{array}$ & 3,75 \\
\hline
\end{tabular}

Ono što je u ovoj tabeli zanimljivo je to da su vaspitači digitalne kompetencije ocenili kao najmanje značajne, što se kosi sa prepoznatom potrebom za posebnim radom na ovim kompetencijama (Pribišev Beleslin, 2012). Ovo možemo pokušati objasniti time šta tačno vaspitači podrazumevaju pod digitalnim kompetencijama, odnosno na šta ih spominjanje digitalnih tehnologija asocira. Trenutno deca provode vreme igrajući igrice i gledajući video zapise natelefonima, tabletima, laptopovimai slično, što vaspitači prepoznaju kao ponašanje koje može negativno da utiče na razvoj dece, odnosno javljaju se određeni stereotipi o lošem uticaju kompjutera na dete u celini, kao i nejasne predstave o značaju interneta u učenju dece (Pribisev Beleslin, 2012). Ali upravo to digitalno okruženje je nešto što ne možemo i ne smemo odvojiti od dece u ovom momentu. Na ovakve rezultate može uticati i digitalna kompetentnost samih vaspitača. Vaspitači koji ne rukuju dobro informacionim tehnologijama će verovatno u manjem obimu koristiti prednosti ovih tehnologija u radu sa decom, a na taj način i samoj deci uskratiti razvoj ovih kompetencija.

„Digitalne kompetencije se razvijaju kroz smisleno korišćenje digitalnih tehnologija kao oruđa kojima se deci omogućava: dolaženje do informacija; izražavanje i predstavljanje u funkciji igre i istraživanja; dokumentovanje različitih aktivnosti“" (Godine uzleta, 2018). Kod dece treba razvijati i adekvatan odnos i kulturu upotrebe digitalnih tehnologija. Ukoliko vaspitači pod digitalnim kompetencijama podrazumevaju bilo šta drugo što se razlikuje od ovoga, neće biti u mogućnosti da sa decom rade na razvoju ovih kompetencija na dobar način. 
Ono što je još iznenađujuće jeste to da su jezičke kompetencije, takođe na veoma nezavidnom pretposlednjem mestu. Razvoj ovih, kao i digitalnih kompetencija se prepoznaje kao jedan od bitnijih. Komunikacija na drugom jeziku je od izuzetne važnosti za funkcionisanje u tehnološkom i informatičkom svetu. Napomenućemo i da se od zaposlenih očekuje da komuniciraju sa partnerima iz različitih delova sveta što će bez poznavanja nekog/nekih stranih jezika biti nemoguće. Još ćemo napomenuti da je predškolski period veoma pogodan period za učenje stranih jezika. Ono čime bismo mogli da objasnimo ove rezultate bilo bi da vaspitači daju veću prednostu u radu sa decom kompetencijama pismenosti u odnosu na jezičke kompetencije. Nailazimo na dosta predškolske dece sa problemima u izgovoru pojedinih glasova, te iz tog razloga vaspitači smatraju da je prvo potrebno raditi na pravilnom izgovaranju svih glasova, širenju vokabulara i usvajanju gramatičkih pravila, a tek kasnije na situacionom usvajanju pojedinih reči iz nekog stranog jezika. Ovi rezultati svakako ostavljaju dosta prostora za dodatna istraživanja kako bismo dobili konkretnija objašnjenja za ovakve stavove vaspitača.

U sledećoj tabeli (Tabela 3) prikazana je razlika u stavovima vaspitača o značaju podrške razvoju ključnih kompetencija prema varijabli mesto rada.

Tabela 3: Razlika u stavovima vaspitača o značaju podrške razvoju ključnih obrazovnih kompetencija prema varijabli mesto rada

\begin{tabular}{|c|c|c|c|c|c|c|c|c|}
\hline \multirow{4}{*}{ 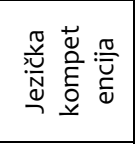 } & Mesto & $\mathrm{N}$ & $M$ & SD & $\mathrm{F}$ & $P$ & \multicolumn{2}{|c|}{$D f$} \\
\hline & Beograd & 60 & 3,90 & ,877 & \multirow{3}{*}{2,700} & \multirow{3}{*}{0,71} & \multirow{3}{*}{$\begin{array}{l}\text { IG } \\
\text { UG } \\
\text { uk. }\end{array}$} & \multirow{3}{*}{$\begin{array}{c}2 \\
146 \\
148\end{array}$} \\
\hline & Manji grad & 60 & 3,72 & ,691 & & & & \\
\hline & Selo & 29 & 4,10 &, 557 & & & & \\
\hline \multirow{4}{*}{ 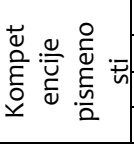 } & Mesto & $\mathrm{N}$ & $M$ & SD & $\mathrm{F}$ & $P$ & & \\
\hline & Beograd & 60 & 4,88 &, 324 & \multirow{3}{*}{1,066} & \multirow{3}{*}{,347 } & IG & 2 \\
\hline & Manji grad & 60 & 4,78 &, 454 & & & UG & 146 \\
\hline & Selo & 29 & 4,79 &, 412 & & & uk. & 148 \\
\hline \multirow{4}{*}{ 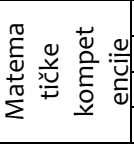 } & Mesto & $\mathrm{N}$ & $M$ & SD & $\mathrm{F}$ & $P$ & & \\
\hline & Beograd & 60 & 4,78 & ,415 & \multirow{3}{*}{2,279} & \multirow{3}{*}{ 106 } & IG & 2 \\
\hline & Manji grad & 60 & 4,63 &, 551 & & & UG & 146 \\
\hline & Selo & 29 & 4,83 &, 384 & & & uk. & 148 \\
\hline \multirow{4}{*}{ 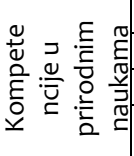 } & Mesto & $\mathrm{N}$ & $\mathrm{M}$ & SD & $\mathrm{F}$ & $P$ & \multirow{4}{*}{\multicolumn{2}{|c|}{$\begin{array}{c}\text { Df } \\
2 \\
146 \\
148\end{array}$}} \\
\hline & Beograd & 60 & 4,38 & ,715 & \multirow{3}{*}{1,861} & \multirow{3}{*}{ 159 } & & \\
\hline & Manji grad & 60 & 4,20 &, 708 & & & & \\
\hline & Selo & 29 & 4,48 & ,688 & & & & \\
\hline \multirow{4}{*}{ 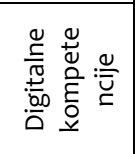 } & Mesto & $\mathrm{N}$ & $M$ & SD & $\mathrm{F}$ & $P$ & & \\
\hline & Beograd & 60 & 3,58 & 1,078 & \multirow{3}{*}{2,987} & \multirow{3}{*}{,054 } & IG & 2 \\
\hline & Manji grad & 60 & 3,73 & 1,006 & & & UG & 146 \\
\hline & Selo & 29 & 4,14 & ,833 & & & uk. & 148 \\
\hline \multirow{4}{*}{ 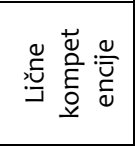 } & Mesto & $\mathrm{N}$ & $M$ & SD & $\mathrm{F}$ & $P$ & & \\
\hline & Beograd & 60 & 4,62 & ,613 & \multirow{3}{*}{,971 } & \multirow{3}{*}{,381 } & IG & 2 \\
\hline & Manji grad & 60 & 4,70 & ,591 & & & UG & 146 \\
\hline & Selo & 29 & 4,79 & ,412 & & & uk. & 148 \\
\hline \multirow{4}{*}{ 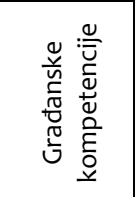 } & Mesto & $\mathrm{N}$ & M & SD & $\mathrm{F}$ & $P$ & & \\
\hline & Beograd & 60 & 4,48 & ,873 & \multirow{3}{*}{,382 } & \multirow{3}{*}{,683 } & \multirow{3}{*}{$\begin{array}{l}\text { IG } \\
\text { UG } \\
\text { uk. }\end{array}$} & \multirow{3}{*}{$\begin{array}{c}2 \\
146 \\
148\end{array}$} \\
\hline & Manji grad & 60 & 4,60 & ,616 & & & & \\
\hline & Selo & 29 & 4,55 & ,632 & & & & \\
\hline
\end{tabular}




\begin{tabular}{|c|c|c|c|c|c|c|c|c|}
\hline \multirow{4}{*}{ 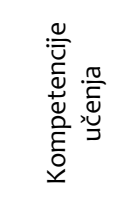 } & Mesto & $\mathrm{N}$ & M & SD & $\mathrm{F}$ & $P$ & & \\
\hline & Beograd & 60 & 4,33 & ,914 & \multirow{3}{*}{1,101} & \multirow{3}{*}{,335 } & \multirow{3}{*}{$\begin{array}{l}\text { IG } \\
\text { UG } \\
\text { uk. }\end{array}$} & \multirow{3}{*}{$\begin{array}{c}2 \\
146 \\
148\end{array}$} \\
\hline & Manji grad & 60 & 4,50 & ,651 & & & & \\
\hline & Selo & 29 & 4,55 &, 572 & & & & \\
\hline \multirow{4}{*}{ 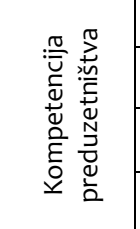 } & Mesto & $\mathrm{N}$ & M & SD & $\mathrm{F}$ & $P$ & & \\
\hline & Beograd & 60 & 4,07 & 1,191 & \multirow{3}{*}{4,269} & \multirow{3}{*}{, 016 } & \multirow{3}{*}{$\begin{array}{l}\text { IG } \\
\text { UG } \\
\text { uk. }\end{array}$} & \multirow{3}{*}{$\begin{array}{c}2 \\
146 \\
148\end{array}$} \\
\hline & Manji grad & 60 & 4,48 & 748 & & & & \\
\hline & Selo & 29 & 4,59 & 628 & & & & \\
\hline \multirow{4}{*}{ 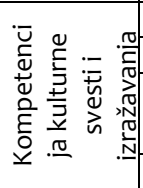 } & Mesto & $\mathrm{N}$ & $M$ & SD & $\mathrm{F}$ & $P$ & & \\
\hline & Beograd & 60 & 4,33 & ,729 & \multirow{3}{*}{1,065} & \multirow{3}{*}{,348 } & \multirow{3}{*}{$\begin{array}{l}\text { IG } \\
\text { UG } \\
\text { uk. }\end{array}$} & \multirow{3}{*}{$\begin{array}{c}2 \\
146 \\
148\end{array}$} \\
\hline & Manji grad & 60 & 4,47 & ,700 & & & & \\
\hline & Selo & 29 & 4,55 & ,686 & & & & \\
\hline
\end{tabular}

Jednofaktorskom analizom varijanse (ANOVA) statistički značajna razlika u značaju koji vaspitači podržavaju razvoj određene komepetencije utvrđena je samo kada je u pitanju kompetencija preduzetništva $\left(F_{=} 4,269 p_{=} 0,016\right)$, dok se na granici značajnosti nalazi digitalna kompetencija $\left(F_{=2}, 987 p_{=0} 0,054\right)$.Vaspitači koji rade u manjem gradu $\left(M_{=}=4,48\right)$ i selu $\left(M_{=} 4,59\right)$, pridaju značajno veći značaj ovoj kompetenciji u odnosu na vaspitače koji rade u Beogradu $\left(M_{=} 4,07\right)$. Ovo bismo mogli objasniti time da vaspitači uviđaju potrebu ljudi koji žive na selu i u manjim gradovima, usled nedostatka šansi za zaposlenje, da sami preduzimaju određene mere, da preuzimaju inicijativu i budu inovativni i na taj način stvore nove mogućnosti za rad i otvaraju svoje firme. Svakako je neophodno da vaspitači uzmu u obzir kontekst u kom se dešava vaspitno-obrazovni proces, a u odnosu na ovaj rezultat, može se reći da je kontekst uticao na njihove stavove.

Za sve ostale navedene kompetencije nisu utvrđene statistički značajne razlike prema varijabli mesto.

U sledećoj tabeli (Tabela 4) prikazane je razlika u stavovima vaspitača o značaju podrške razvoju ključnih kompetencija prema varijabli godine radnog staža.

Tabela 4: Razlika u stavovima vaspitača o značaju podrške razvoju ključnih obrazovnih kompetencija prema varijabli GRS

\begin{tabular}{|c|c|c|c|c|c|c|c|c|}
\hline \multirow{4}{*}{ 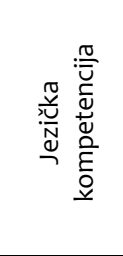 } & GRS & $\mathrm{N}$ & $M$ & SD & $\mathrm{F}$ & $P$ & & \\
\hline & Do 10 GRS & 56 & 3,82 & 811 & \multirow{3}{*}{ 153 } & \multirow{3}{*}{,859 } & \multirow{3}{*}{$\begin{array}{l}\text { IG } \\
\text { UG } \\
\text { uk. }\end{array}$} & \multirow{3}{*}{$\begin{array}{r}2 \\
146 \\
148\end{array}$} \\
\hline & $\begin{array}{l}\text { Od } 10 \text { do } \\
20 \text { GRS }\end{array}$ & 54 & 3,89 & ,691 & & & & \\
\hline & $\begin{array}{c}\text { Preko } 20 \\
\text { GRS }\end{array}$ & 39 & 3,90 & ,788 & & & & \\
\hline \multirow{3}{*}{ 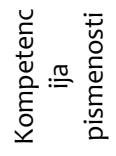 } & GRS & $\mathrm{N}$ & $M$ & SD & $\mathrm{F}$ & $P$ & & \\
\hline & Do 10 GRS & 56 & 4,80 & ,401 & \multirow{2}{*}{,865 } & \multirow{2}{*}{,423 } & \multirow{2}{*}{$\begin{array}{l}\text { IG } \\
\text { UG } \\
\text { uk. }\end{array}$} & \multirow{2}{*}{$\begin{array}{r}2 \\
146 \\
148\end{array}$} \\
\hline & Od 10 do & 54 & 4,80 & ,451 & & & & \\
\hline
\end{tabular}




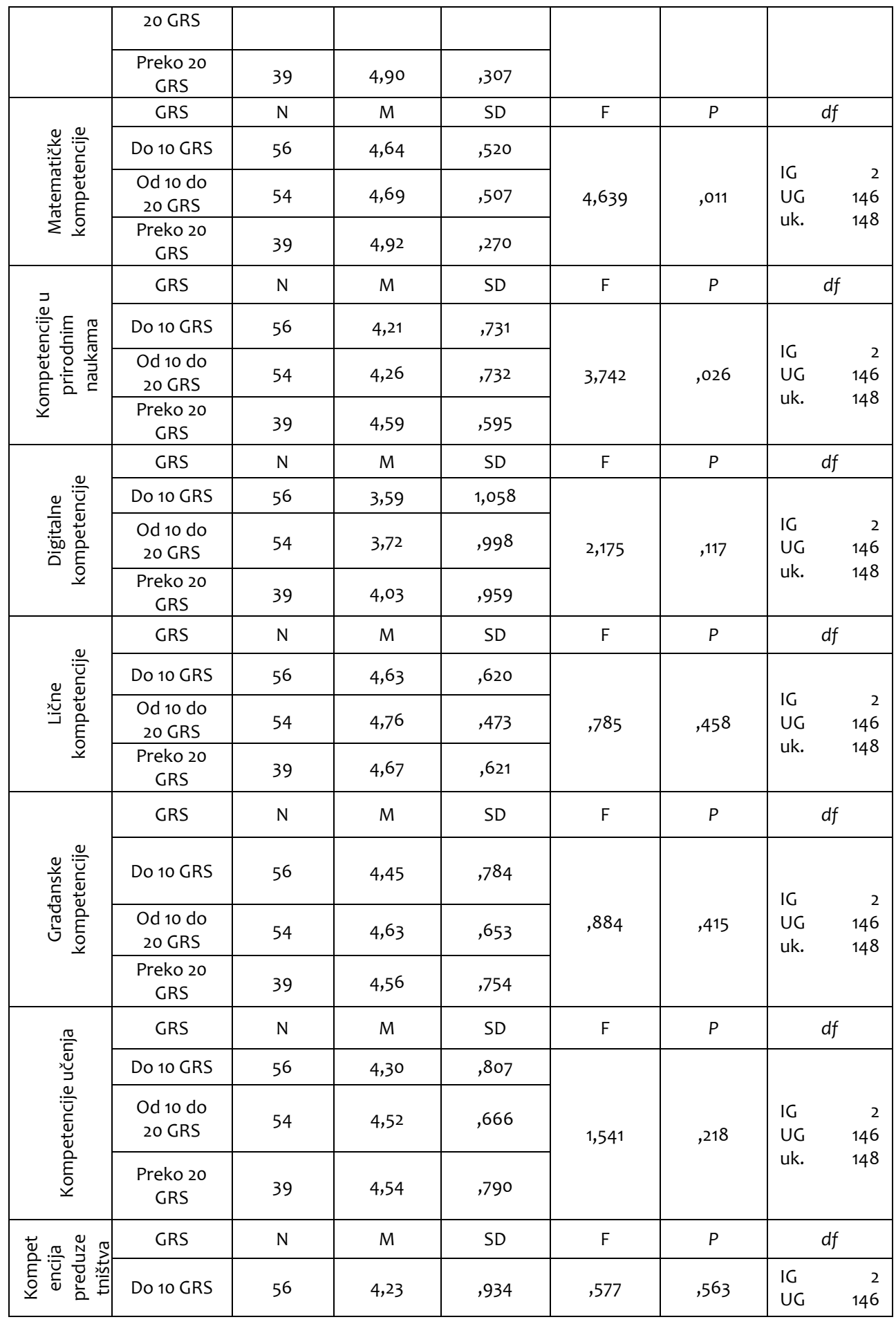




\begin{tabular}{|c|c|c|c|c|c|c|c|c|}
\hline & $\begin{array}{l}\text { Od } 10 \text { do } \\
20 \text { GRS }\end{array}$ & 54 & 4,43 & ,838 & & & \multirow[t]{2}{*}{ uk. } & \multirow[t]{2}{*}{148} \\
\hline & $\begin{array}{c}\text { Preko } 20 \\
\text { GRS }\end{array}$ & 39 & 4,36 & 1,135 & & & & \\
\hline \multirow{4}{*}{ 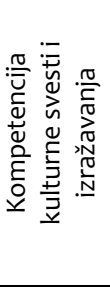 } & GRS & $N$ & M & SD & $\mathrm{F}$ & $P$ & & \\
\hline & Do 10 GRS & 56 & 4,27 & ,798 & \multirow{3}{*}{4,342} & \multirow{3}{*}{, 015} & \multirow{3}{*}{$\begin{array}{l}\text { IG } \\
\text { UG } \\
\text { uk. }\end{array}$} & \multirow{3}{*}{$\begin{array}{r}2 \\
146 \\
148\end{array}$} \\
\hline & $\begin{array}{l}\text { Od } 10 \text { do } \\
20 \text { GRS }\end{array}$ & 54 & 4,41 & ,687 & & & & \\
\hline & $\begin{array}{c}\text { Preko } 20 \\
\text { GRS }\end{array}$ & 39 & 4,69 & ,521 & & & & \\
\hline
\end{tabular}

Jednofaktorskom analizom varijasne (ANOVA) statistički značajna razlika u stavovima vaspitača o značaju pojedinačnih kompetencija za celokupan razvoj dece, utvrđena je kada su u pitanju sledeće kompetencije: matematičke kompetencije $\left(F_{=4} 4,639 ; p_{=}, 011\right)$, kompetencije $u$ prirodnim naukama $\left(F_{=3}, 742 ; p_{=}, 026\right)$ i kompetencije kulturne svesti i izražavanja $\left(F_{=} 4,342 p_{=}, 015\right)$. $\mathrm{U}$ sva tri slučaja, vaspitači čije je radno iskustvo duže od 20 godina, ovim kompetencijama pridaju veći značaj, u odnosu na vaspitače čije je radno iskustvo manje od 20 godina. Ovo bismo mogli objasniti time da vaspitači čije je radno iskustvo duže od 20 godina, poučeni tim istim iskustvom, uviđaju da rad na razvoju ove tri kompetencije ima zapravo veliki doprinos za razvoj deteta u celini, što možda vaspitači čije je radno iskustvo manje (kraće), ne uviđaju na početku. Takođe, vaspitači sa više godina radnog staža imaju iskustvo u radu prema nekim ranijim konceptima predškolskog vaspitanja i obrazovanja koje su se oslanjale na vaspitnoobrazovni rad prema određenim oblastima ili aspektima razvoja i u kojima je ovladavanju matematičkim pojmovima, upoznavanju sveta oko sebe i razvoju komunkacije i izražavanja bio dat značajan prostor u celokupnom radu. Moguće je da u objašnjenju ovih kompetencija vaspitači prepoznaju određene sadržinske oblasti ili aspekte vaspitno-obrazovnog rada sa decom karakteristične za koncepcije koje su bile dominantne pre donošenja Novih osnova progama.

\section{Zaključna razmatranja}

Ovaj istraživanje je jedno od prvih u nizu istraživanja koje želimo da uradimo na temu razvoja ključnih kompetencija za celoživotno učenje u radu sa predškolskom decom u Srbiji. Pregledom dostupne literature nećemo naići na puno radova sa ovom tematikom. Rezultati do kojih smo došli ovim malim istraživanjem ukazuju nam na pravce u kojima dalja istraživanja mogu ići, a tiču se spremnosti vaspitača za pružanje podrške razvoju ključnih obrazovnih kompetencija za celoživotno učenje. Istraživanja mogu ići i u pravcu sadržaja inicijalnog obrazovanja vaspitača, ali i u pravcu detaljnijeg bavljenja razlozima u odnosu na koje vaspitači daju manje ili više prostora svakoj od pojedinačnih ključnih obrazovnih kompetencija u vaspitno-obrazovnom radu sa decom predškolskog uzrasta, kao načinima na koje vaspitači pružaju deci mogućnost da razvijaju svaku od ovih kompetencija. Dobijeni podaci mogu biti indikator da vaspitači nisu dovoljno informisani o tome šta se pod određenim kompetencijama podrazumeva i na tome je potrebno raditi. Podrška razvoju ovih kompetencija u toku predškolskog vaspitanja i obrazovanja je od velikog značaja za nastavak razvoja kompetencija tokom daljeg školovanja i života uopšte. Deca predškolskog uzrasta su rođenjem motivisana za učenje i otkrivanje sveta oko sebe te bi bilo veoma dragoceno za njihov celokupan razvoj iskorisititi njihovu urođenu radoznalost i želju za učenje i saznavanje za razvoj ključnih obrazovnih kompetencija i dispozicija za učenje. 


\section{Literatura}

Buđevac, N. i Kovacevic, Z. (2020). Sagledavanje deteta i procesa učenja u novim osnovama programa predškolskog vaspitanja i obrazovanja. Ur. Z. Opačić: Knjiga rezimea /Međunarodni naučni skup Programske (re)forme u obrazovanju i vaspitanju - izazovi i perspektive (463-476). Beograd: Uciteljski fakultet.

Dmitrovic, P. (2011). Moguci putevi modernizacije vaspitno-obrazovnog procesa. Preuzeto sa: http://www.ftn.kg.ac.rs/konferencije/tio6/radovi/2)\%20Pedagoske\%20dimenzije\%20dr ustva\%20ucenja\%20i\%20znanja/PDF/202\%20Petar\%20Dmitrovic.pdf 25. 3. 2021.

EuropeanCommission. (2018b). Annex to the Proposal for a Council Recommendation on Key Competences for Lifelong Learning.

European Commission. (2018a). Proposal for a council recommendation on key competences for lifelong learning.

Godine uzleta - Osnove programa predskolskog vaspitanja i obrazovanja (2018). Beograd: Republika Srbija Ministarstvo prosvete, nauke i tehnoloskog razvoja.

Kovačević, Z. (2017). Samostalni rad dece i učenika u oblasti upoznavanja i razumevanja sveta i nastavi prirode i drustva. Nastava i vaspitanje, 2017 (2), 239-258.

Maksimović, I. (2012). Celoživotno učenje: ključne kompetencije. Naslede, 2012 (21), 231-245.

Manic Radoicic, J. Durovic, A. (2018). Obrazovanje i vestine u Evropskoj uniji i Srbiji. Standardi EU u obarzovanju u Srbiji. Ur. D. Milenkovic. Beograd: Evropski pokret u Srbiji.

Obrazovanje u Srbiji: kako do boljih rezultata - Pravci razvoja i unapređivanja kvaliteta predskolskog, osnovnog, opsteg srednjeg i umetnickog obrazovanja i vaspitanja2010-2020 (2011). Beograd: Nacionalni prosvetni savet.

Pavićević, M., Petrović, D. (2015). Razlike izmedu formalnog, neformalnog i informalnog obrazovanja. U P. Rajcevic: Zbornik radova Uciteljskog fakulteta knjiga9(str. 103-113). Leposavic: Uciteljski fakultet u Prizrenu.

Prastalo, R. (2010). Kompetencije i karijera. Dostupno na: https://prastaloradojka.files.wordpress.com/2014/12/kompetencije_i_karijera.pdf 16. 3. 2021.

Pribišev Beleslin, T. (2012). Vaspitanje i obrazovanje u ranom detinjstvu u postinformaticko doba: pogled na digitalno odrastanje i digitalne podele male dece. U I. Pehlic, E. Vejo, A. Hasanagic: Suvremeni tokovi u ranom odgoju znanstvena monografija (str. 39-56). Zenica: Islamski pedagoski fakultet Univerziteta u Zenici.

Radulovic, L. (2016.) Slike o nastavniku - izmedu moderne i postmoderne. Beograd: Institut za pedagogiju i andragogiju Filozofskog fakulteta Univerziteta u Beogradu.

Razvoj politike celozvotnog vodenja; Evropski paket resursa. U: R. Vuorinen i A. Vats. Preuzeto sa: http://www.elgpn.eu/publications/browse-by-language/serbian/razvoj-politikietsielozhivotnogh-vodjienja-ievropski-pakiet-riesursa/4.3. 2021

Standardi opstih medupredmetnih kompetencija za kraj srednjeg obrazovanja (2013).Beograd: Zavod za vrednovanje kvaliteta obrazovanja i vaspitanja.

Strategija razvoja obrazovanja u Srbiji do 2020. godine (2012). Sluzbeni glasnik RS, br. 107/2012 od 9.11.2012. godine. Beograd.

Vukovic, O. (2015). Kako maturanti procenjuju znacaj kljucnh kompetencija za celozivotno ucenje. U: Radosavljevic, D. Vrednosti i identitet(89-96). NoviSad: FakultetzapravneiposlovnestudijedrLazarVrkatic. (http://naucniskup.fpps.edu.rs/PDF/Zbornik\%205\%20prelom-za\%20cip.pdf\#page=89) 11. 3.2021.

Woodhead, M. (2012) Razlicite perspective o ranom detinjstvu: teorija, istrazivanje i politika. Beograd: Institut za pedagogiju i andragogiju Filozofskog fakulteta u Beogradu CIP Centar za interaktivnu pedagogiju, 
Zakon o nacionalnom okviru kvalifikacija Republike Srbije (2020). Sluzbeni glasnik RS, br. 27/2018 i 6/2020. Preuzeto sa: https://www.paragraf.rs/propisi/zakon-o-nacionalnom-okvirukvalifikacija-republike-srbije.html 12.3. 2021.

\section{Biografija}

Miljana Mićović je rođena 1995. godine u Pančevu. Osnovne i master studije završila je na Učiteljskom fakultetu Univerziteta u Beogradu. Od 2018. godine radi kao saradnikdemonstrator na predmetu Didaktika sa metodikom vaspitno-obrazovnog rada. 